\title{
Effect of the mass of immunoglobulin (Ig)G intake and age at first colostrum feeding on serum IgG concentration in Holstein calves
}

\author{
I. Osaka, ${ }^{* 1}$ Y. Matsui, ${ }^{*}$ and F. Terada† \\ *Hokkaido Research Organization, Konsen Agricultural Research Center, Nakashibetsu, Hokkaido, Japan 0861135 \\ †National Agriculture and Food Research Organization, Kyushu Okinawa Agricultural Research Center, Koshi, Kumamoto, Japan 8611192
}

\begin{abstract}
Forty-four Holstein calves (19 male and 25 female) were used in this study of the relationships among age at first colostrum feeding, IgG intake, and apparent efficiency of $\operatorname{IgG}$ absorption. Time of birth was recorded for each calf and the calves were fed colostrum ad libitum after birth at either 0930 or $1630 \mathrm{~h}$. Blood samples were collected immediately before and $24 \mathrm{~h}$ after colostrum feeding. Data from calves were then categorized into 4 groups representing time from birth to colostrum feeding: $\mathrm{A}=$ fed within $1 \mathrm{~h}(\mathrm{n}=5) ; \mathrm{B}=$ fed from 1 to $6 \mathrm{~h}(\mathrm{n}=10) ; \mathrm{C}=$ fed from 6 to $12 \mathrm{~h}(\mathrm{n}=21)$; and $\mathrm{D}$ $=$ fed from 12 to $18 \mathrm{~h}(\mathrm{n}=8)$ after birth. Average total intake of colostrum was $3.6 \pm 0.1 \mathrm{~L}$. Over $80 \%$ of the calves consumed $\geq 3 \mathrm{~L}$ of colostrum. Apparent efficiency of IgG absorption declined remarkably $12 \mathrm{~h}$ after birth. Mean apparent efficiency of absorption of IgG in group $\mathrm{D}(15.8 \pm 3.0 \%)$ was lower than that in groups A $(30.5$ $\pm 3.9 \%)$ and B $(27.4 \pm 2.8 \%)$. Serum IgG concentration in calves was positively correlated with IgG intake in all groups. The relationship between mass of IgG consumed and calf serum IgG at $24 \mathrm{~h}$ was different for each time of colostrum feeding, with only limited differences observed between groups A and B. We concluded that failure of transfer of passive immunity in newborn calves may be avoided if calves consume $\geq 3 \mathrm{~L}$ of colostrum with $\operatorname{IgG}$ concentration $>40 \mathrm{mg} / \mathrm{mL}$ within $6 \mathrm{~h}$ after birth. These findings help define the opportunity to minimize failure of transfer of passive immunity to newborn calves under management programs similar to those used on commercial dairy farms.
\end{abstract}

Key words: immunoglobulin G intake, age at first colostrum feeding, apparent efficiency of absorption

\section{INTRODUCTION}

Calves are defined as experiencing failure of passive transfer (FPT) when serum IgG concentration is

Received October 7, 2013.

Accepted June 7, 2014.

${ }^{1}$ Corresponding author: osaka-ikuo@hro.or.jp
$<10 \mathrm{mg} / \mathrm{mL}$ at 24 and $48 \mathrm{~h}$ after birth (Weaver et al., 2000). Calves with low serum IgG concentrations are at greater risk for preweaning morbidity and mortality than calves with higher concentrations of IgG (National Animal Health Monitoring System, 1996). Mortality rate of calves with serum IgG concentration $<10 \mathrm{mg} /$ $\mathrm{mL}$ was more than twice as high as that of calves with higher IgG concentrations (Wells et al., 1996).

The primary factors that influence transfer of $\operatorname{IgG}$ from the colostrum are the age of the calf at the first colostrum feeding and the mass of IgG intake (Stott et al., 1979a,b). Staley and Bush (1985) reported that intestinal epithelial cells in calves lost their ability to absorb intact macromolecules after about $24 \mathrm{~h}$. Apparent efficiency of $\operatorname{IgG}$ absorption (AEA) from the small intestine of calves declines soon after birth (Abel Francisco and Quigley, 1993; Rajala and Castrén, 1995). Hopkins and Quigley (1997) showed that serum IgG concentration was positively correlated with IgG intake. Therefore, it is recommended that neonatal calves be supplied adequate high-quality colostrum mass as soon as possible after birth (NRC, 2001).

Several researchers suggest that calves should be provided approximately $4 \mathrm{~L}$ of colostrum (Roy, 1980; Besser et al., 1991; Hopkins and Quigley, 1997). However, additional labor is often needed when feeding more colostrum with an esophageal feeder than calves may consume ad libitum or when feeding colostrum more frequently. Limited data (Hopkins and Quigley, 1997) are available that show the mass of colostrum that calves are able to consume ad libitum at the first feeding.

Todd and Whyte (1995) reported that serum IgG concentration of calves was not significantly different when the age at first colostrum feeding occurred between 1 and $8 \mathrm{~h}$ after birth. They considered that the high IgG concentration of the colostrum they fed to calves may have compensated for any loss of absorption efficiency associated with delays in the first feeding. In that controlled study, IgG intake was held constant. However, the amount of colostrum and the mass of IgG that calves consume is often not easily controlled in onfarm environments without a significant labor cost. The 
goal of this study was to better define the relationships between calf age at colostrum feeding, voluntary intake of colostrum, and apparent efficiency of IgG absorption in calves under management schemes typical of dairy farms. Results from this study may be used in development of newborn calf management protocols.

\section{MATERIALS AND METHODS}

Animal management and blood sampling were carried out according to the guidelines for animal experiments of Hokkaido Animal Research Center at Shintoku (Hokkaido, Japan). The present study included 44 Holstein dairy calves (19 male and 25 female) from the Hokkaido Animal Research Center. The birth of each calf was carefully observed and calves were immediately separated from their dams to avoid suckling. Time of birth was recorded and calves were weighed and placed in a dry, disinfected pen with straw bedding until colostrum feeding. Cows were milked at either 0600 or $1600 \mathrm{~h}$ for the first time after calving, and first-milking colostrum was used to feed each cow's own calf. The time of feeding colostrum to calves was fixed at either 0930 or $1630 \mathrm{~h}$. Calves were initially offered $4 \mathrm{~L}$ of their dam's colostrum using a nipple pail. If it was apparent that the calf would consume all $4 \mathrm{~L}$ of colostrum, an additional $2 \mathrm{~L}$ of colostrum was added to the nipple pail. In some cases, dams did not yield sufficient colostrum to meet the intake of the calf or colostrum from the dam was not otherwise available. In those cases, frozen colostrum from other cows (colostrometer reading of $>1.050$ ) was thawed and used to supplement the dam's colostrum. Calves were fed their dam's colostrum first before the thawed colostrum source was fed. Frozen colostrum was stored in plastic bags at $-30^{\circ} \mathrm{C}$. Frozen colostrum was thawed by sealing the bag in a second bag and immersing the bag in water at 40 to $45^{\circ} \mathrm{C}$ until thawed. The volume of colostrum consumed was determined by the difference between the quantity offered to the calf and the residual colostrum left in the pail after feeding. Blood samples were collected just before and 24 $\mathrm{h}$ after colostrum feeding. Data from calves were then categorized into 4 groups representing time from birth to colostrum feeding. The groups were as follows: $\mathrm{A}=$ colostrum fed within $1 \mathrm{~h}(\mathrm{n}=5)$; $\mathrm{B}=$ colostrum fed between 1 and $6 \mathrm{~h}(\mathrm{n}=10) ; \mathrm{C}=$ colostrum fed between 6 and $12 \mathrm{~h}(\mathrm{n}=21)$; and $\mathrm{D}=$ colostrum fed between 12 and $18 \mathrm{~h}(\mathrm{n}=8)$ after birth. One calf consumed only $1.5 \mathrm{~L}$ at 20 min after birth and was excluded from the data set. The number of calves that received only frozen colostrum was 1, 2, 3, and 0 for groups A, B, C, and D, respectively. Calves were not fed milk for $24 \mathrm{~h}$ after the feeding of colostrum. Calves were then fed 2 $\mathrm{L}$ of fresh milk from a nipple pail at 0930 and $1630 \mathrm{~h}$.
Samples of colostrum fed to each calf were collected for IgG analysis. Colostrum was centrifuged at 18,000 $\times g$ for $30 \mathrm{~min}$ at $4^{\circ} \mathrm{C}$ and the supernatant collected and stored at $-30^{\circ} \mathrm{C}$. Blood samples were collected from calves by jugular venipuncture with a $10-\mathrm{mL}$ syringe and 18-gauge needle, and blood was transferred to a plastic evacuated tube (Venoject II, Terumo Inc., Tokyo, Japan). Blood was allowed to clot at room temperature for $30 \mathrm{~min}$ and serum was collected after centrifugation at $2,000 \times g$ for $10 \mathrm{~min}$ at $20^{\circ} \mathrm{C}$. Serum was stored at $-30^{\circ} \mathrm{C}$. Concentration of $\operatorname{IgG}$ in defatted colostrum and serum samples was determined by single radial immunodiffusion (The Institute for Metabolic Ecosystem Inc., Miyagi, Japan), according to the manufacturer's instructions.

Intake of IgG, serum IgG and AEA of IgG were calculated as per Quigley and Drewry (1998), where

$$
\begin{gathered}
\text { IgG intake }(\mathrm{g})=\operatorname{IgG} \text { concentration in milk } \\
(\mathrm{mg} / \mathrm{mL}) \times \text { milk volume }(\mathrm{L}),
\end{gathered}
$$

serum $\operatorname{IgG}(\mathrm{g})=\operatorname{IgG}$ concentration in serum

$$
(\mathrm{mg} / \mathrm{mL}) \times \text { serum volume }(\mathrm{L}) \text {, and }
$$

$\operatorname{AEA}(\%)=[$ serum $\operatorname{IgG}(\mathrm{g}) / \operatorname{IgG}$ intake $(\mathrm{g})] \times 100$

Serum volume (L) was estimated using the value of $7 \%$ of BW at birth, which has been used by others in determining AEA (Quigley and Drewry, 1998).

Statistical analyses were performed using SAS software (version 9.3, SAS Institute Inc., Cary, NC). Descriptive data at the first colostrum feeding were analyzed by 1-way ANOVA using the GLM procedure. Treatment means were separated using the least significant difference test when a significant treatment effect was observed. Statistical differences were considered significant at $P<0.05$. The relationship between AEA and age at first colostrum feeding was analyzed by using the NLIN procedure to perform breakpoint analysis. A regression analysis with the REG procedure was used to assess the association between IgG intake and serum $\operatorname{IgG}$ concentrations at $24 \mathrm{~h}$ after colostrum intake in each group.

\section{RESULTS}

Birth weight of calves was not different among groups (Table 1). The age at colostrum feeding across all calves ranged from 20 min (calf consumed only $1.5 \mathrm{~L}$ of colostrum) to $17.8 \mathrm{~h}$; mean age at colostrum feeding was different for each group (Table 1). Mean colostrum intake volume was $3.6 \pm 0.1 \mathrm{~L}$ and ranged from 1.5 


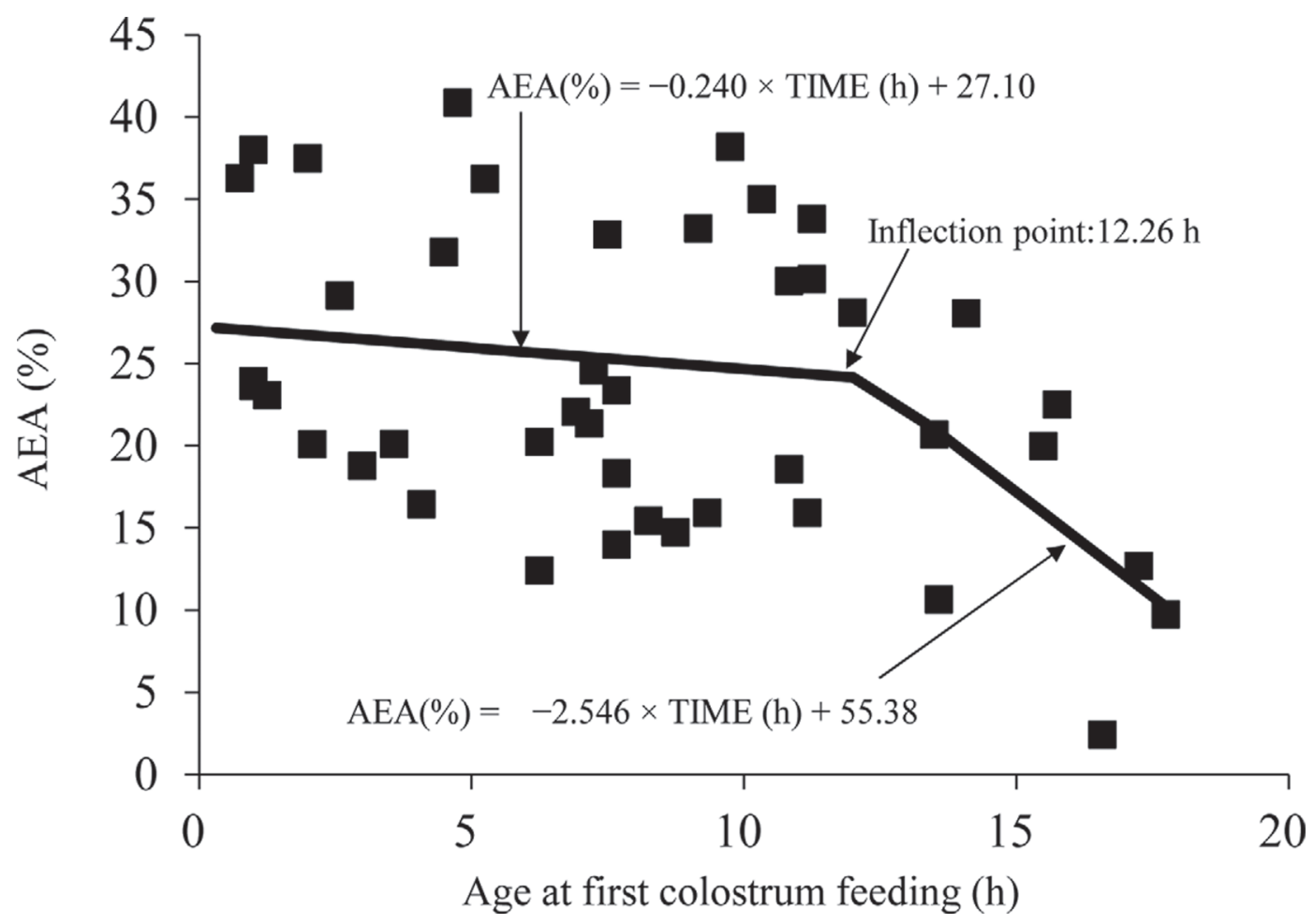

Figure 1. Relationship between age at colostrum feeding and apparent efficiency of absorption (AEA) of IgG. Breakpoint analysis indicates that the decline in AEA accelerates $12 \mathrm{~h}$ after colostrum feeding.

to $5.2 \mathrm{~L}$ for all calves. Birth weight, colostrum intake, and the ratio of colostrum intake to birth weight were not significantly different among groups. Eighty-four percent of all calves (36 of 43 total calves) consumed $>3 \mathrm{~L}$ of colostrum. Of the calves consuming $<3 \mathrm{~L}$ of colostrum, the average colostral intake volume was 2.7 $\mathrm{L}$ and ranged from 2.4 to $2.9 \mathrm{~L}$.

The relationship between AEA and age at first colostrum feeding is shown in Figure 1. We observed wide variation in $\mathrm{AEA}$; however, $\mathrm{AEA}$ tended to decline slowly to an inflection point at $12.26 \mathrm{~h}$, after which time it declined more rapidly. Mean AEA of group D was significantly lower $(P<0.05)$ than that of group A or B (Table 1).

The relationship between mass of $\mathrm{IgG}$ intake and the resulting calf serum IgG concentration at $24 \mathrm{~h}$ after colostrum intake is illustrated in Figure 2. Concentration of $\mathrm{IgG}$ in calf serum at $0 \mathrm{~h}$ was below the detection limits of the assay and therefore regarded as $0 \mathrm{mg} / \mathrm{mL}$. As IgG intake increased, serum IgG concentrations also

Table 1. Characteristics of calves and colostrum consumption of calves in 4 groups $^{1}$

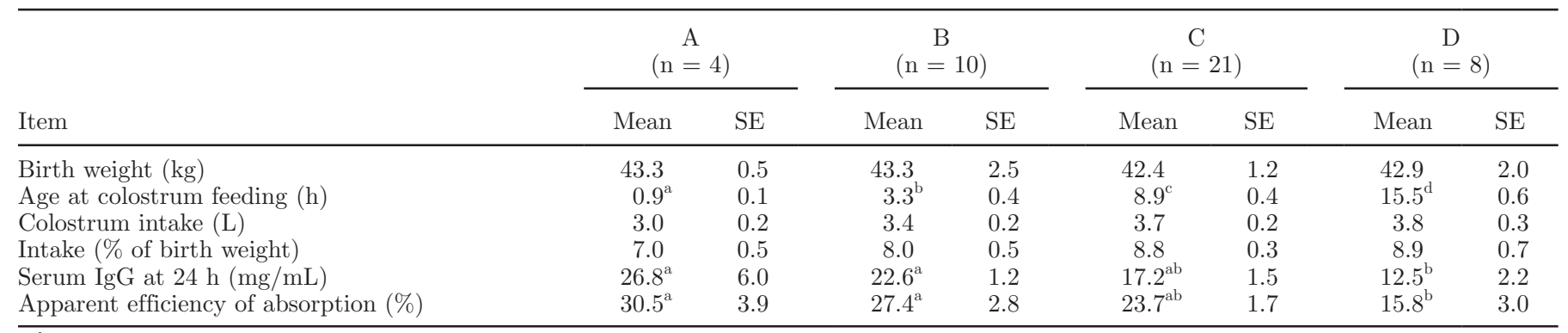

${ }^{\mathrm{a}-\mathrm{d}}$ Means within rows with different superscripts differ $(P<0.05)$.

${ }^{1}$ Calf groups are as follows: $\mathrm{A}=$ fed colostrum 0 to $1 \mathrm{~h}$ after birth; $\mathrm{B}=$ fed colostrum 1 to $6 \mathrm{~h}$ after birth; $\mathrm{C}=$ fed colostrum 6 to $12 \mathrm{~h}$ after birth; and $\mathrm{D}=$ fed colostrum 12 to $18 \mathrm{~h}$ after birth. 


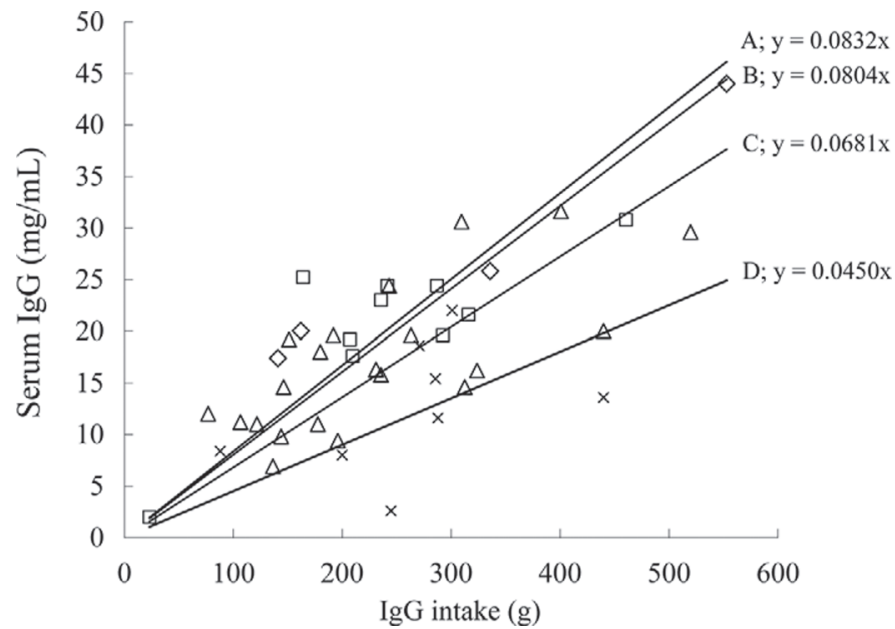

Figure 2. Relationship between mass of $\operatorname{IgG}$ consumed by the calf and serum $\mathrm{IgG}$ concentration at $24 \mathrm{~h}$ after colostrum feeding. Calf groups are as follows: $\mathrm{A}(\diamond$; fed colostrum $0-1 \mathrm{~h}$ after birth $), \mathrm{B}=(\square$; fed colostrum 1-6 h after birth), $\mathrm{C}(\Delta$; fed colostrum $6-12 \mathrm{~h}$ after birth), and D ( $\times$; fed colostrum $12-18 \mathrm{~h}$ after birth).

increased in all groups. However, the slope of regression declined with increasing age at colostrum feeding, consistent with the declining AEA.

\section{DISCUSSION}

The purpose of this study was to more clearly define the relationships between age at first feeding of colostrum, volume of colostrum consumed, and mass of IgG consumed by the calf relative to the resulting calf serum IgG concentrations. These relationships were characterized under management protocols that reflected typical on-farm care of newborn calves. Consumption of high-quality colostrum (high concentrations of $\operatorname{IgG}$ ) is important to ensure that adequate serum IgG concentrations are attained in the calf (Jaster, 2005). Others have recommended that calves be fed $>100 \mathrm{~g}$ of IgG in the first colostrum feeding (Davis and Drackley, 1998). Results from the present study demonstrate that calves need to consume $120 \mathrm{~g}$ of $\operatorname{IgG}$ if fed in the first hour after birth or $125 \mathrm{~g}$ of $\mathrm{IgG}$ if fed between 1 and 6 $\mathrm{h}$, to achieve $10 \mathrm{mg} / \mathrm{mL}$ of serum $\operatorname{IgG}$ at $24 \mathrm{~h}$. These data suggest that a serum IgG concentration $>10 \mathrm{mg} /$ $\mathrm{mL}$ would be achieved if calves consumed $3 \mathrm{~L}$ of colostrum containing $\geq 40 \mathrm{mg} / \mathrm{ml} \mathrm{IgG}$ in one feeding within $6 \mathrm{~h}$ after birth.

Increasing colostrum intake is one important factor to avoid FPT. Earlier studies suggested that newborn calves should receive approximately $2 \mathrm{~L}$ of colostrum in the first few hours after birth (Stott et al., 1979a; Roy, 1980). Others have indicated that colostrum volume is negatively correlated with colostrum $\mathrm{IgG}_{1}$ concen- tration (Pritchett et al., 1991). Besser et al. (1991) reported that calves often receive an inadequate mass of immunoglobulin when $2 \mathrm{~L}$ of first-milking colostrum is fed. To maximize serum immunoglobulin concentrations, therefore, recommended colostrum feeding methods indicate that neonatal calves should be fed greater quantities of colostrum ( $>2 \mathrm{~L}$ ) as early as possible after birth. Roy (1980) suggested that calves should consume $4 \mathrm{~L}$ of colostrum divided into 2 feedings within $12 \mathrm{~h}$ after birth. Besser et al. (1991) and Morin et al. (1997) also reported that serum immunoglobulin concentration was greater when calves were fed $4 \mathrm{~L}$ of colostrum at birth versus $2 \mathrm{~L}$ at birth or $2 \mathrm{~L}$ at $12 \mathrm{~h}$. In the latter study, colostrum was administered to calves by esophageal feeder to achieve the expected colostrum intake. Hopkins and Quigley (1997) reported that mean consumption of colostrum by calves was $3.0 \mathrm{~L}$ when calves were offered $3.8 \mathrm{~L}$ of colostrum in 1 feeding at a mean of $1.3 \mathrm{~h}$ after birth.

In the present study, the colostrum intake measurements indicated that $3 \mathrm{~L}$ of colostrum could be consumed without esophageal tube administration for most calves at the first feeding, regardless of time after birth. We observed that colostrum intake by one calf at 20 min after birth was only $1.5 \mathrm{~L}$. That calf could not yet stand on its own and did not show a significant appetite for colostrum. It may be that a calf's ability to consume colostrum immediately after birth is limited.

Intestinal epithelial cells lose their ability to absorb intact macromolecules as the age of the newborn increases (Staley and Bush, 1985). In the calf, AEA decreases from birth to essentially zero at approximately $24 \mathrm{~h}$ (Weaver et al., 2000). In the current study, AEA varied widely within each group (Figure 1). Although Stott and Fellah (1983) indicated that AEA was improved by feeding $1 \mathrm{~L}$ of colostrum compared with feeding an equivalent mass of immunoglobulin in $2 \mathrm{~L}$ of colostrum, others have observed that increasing the IgG mass by feeding supplemental colostrum replacer decreased the AEA of IgG (Besser et al., 1985; Campbell et al., 2007). Those studies differed in the mass of immunoglobulin fed, with $<130 \mathrm{~g}$ being fed in the Stott and Fellah (1983) study, 100 to $700 \mathrm{~g}$ in Besser et al. (1985), and 130 to $390 \mathrm{~g}$ in Campbell et al. (2007). Besser et al. (1985) considered that calves had a physiologic limitation for absorption of immunoglobulin. In the present study, wide variation in AEA was observed within each group, which probably reflects the wide range of IgG mass consumed (from 23 to $553 \mathrm{~g}$ ). Although calves begin to lose the ability to absorb macromolecules such as immunoglobulin (Abel Francisco and Quigley, 1993; Rajala and Castrén, 1995), results from the present study suggest that the decline in AEA occurs at a slower rate early after birth followed by a 
much faster rate after about $12 \mathrm{~h}$. These data suggest that AEA in the initial hours after birth is influenced more by the mass of immunoglobulin consumed than by age at the first colostrum feeding, at least within the first $6 \mathrm{~h}$ after birth.

The relationship between IgG intake and calf serum IgG was linear and positive (Figure 2), in agreement with observations by Hopkins and Quigley (1997). In the present study, the effect of age of calf at colostrum feeding on the relationship between IgG intake and IgG serum concentration was also evaluated. We observed that the slope of regression lines declined with increasing age at colostrum feeding.

\section{CONCLUSIONS}

In this study, AEA and serum IgG concentration in calves at $24 \mathrm{~h}$ was significantly influenced by the mass of $\mathrm{IgG}$ consumed. Apparent efficiency of absorption of IgG declined by less than $0.3 \% / \mathrm{h}$ from calving to 12 after birth, and then declined more rapidly at $2.5 \% / \mathrm{h}$ to at least $18 \mathrm{~h}$ after birth. For supplying sufficient IgG to calves, the mass of $\mathrm{IgG}$ intake was more important than age at first colostrum feeding within the limited early period of macromolecular transport. Most calves could consume at least $3 \mathrm{~L}$ of colostrum in one feeding. Therefore, calves consuming at least $3 \mathrm{~L}$ of colostrum containing $\geq 40 \mathrm{mg} / \mathrm{mL}$ of $\mathrm{IgG}$ should avoid failure of transfer of passive immunity.

\section{REFERENCES}

Abel Francisco, S. F., and J. D. Quigley III. 1993. Serum immunoglobulin concentration in response to maternal colostrum and colostral supplementation in dairy calves. Am. J. Vet. Res. 54:1051-1054.

Besser, T. E., A. E. Garmedia, T. C. McGuire, and C. C. Gay. 1985. Effect of colostral immunoglobulin $\mathrm{IgG}_{1}$ and immunoglobulin $\mathrm{M}$ concentration on immunoglobulin $\operatorname{IgG}_{1}$ absorption in calves. J Dairy Sci. 68:2033-2037.

Besser, T. E., C. C. Gay, and L. Pritchett. 1991. Comparison of three methods of feeding colostrum to dairy calves. J. Am. Vet. Med. Assoc. 198:419-422.

Campbell, J. M., L. E. Russell, J. D. Crenshow, E. M. Weaver, S. Godden, J. D. Quigley, J. Coverdale, and H. Tyler. 2007. Impact of irradiation and immunoglobulin $\mathrm{G}$ concentration on absorption of protein and immunoglobulin $\mathrm{G}$ in calves fed colostrum replacer. J. Dairy Sci. 90:5726-5731.

Davis, C. L., and J. K. Drackley. 1998. Colostrum. Pages 179-206 in The Development, Nutrition, and Management of the Young Calf. 1st ed. Iowa Sate University Press, Ames.

Hopkins, B. A., and J. D. Quigley III. 1997. Effects of method of colostrum feeding and colostrum supplementation on concentrations of immunoglobulin G in the serum of neonatal calves. J. Dairy Sci. 80:979-983.

Jaster, E. H. 2005. Evaluation of quality, quantity, and timing of colostrum feeding on immunoglobulin $\mathrm{G}_{1}$ absorption in Jersey calves. J. Dairy Sci. 88:296-302.

Morin, D. E., G. C. McCoy, and W. L. Hurley. 1997. Effects of quality, quantity, and timing of colostrum feeding and addition of a dried colostrum supplement on immunoglobulin $\mathrm{G}_{1}$ absorption in Holstein bull calves. J. Dairy Sci. 80:747-753.

National Animal Health Monitoring System. 1996. NAHMS Dairy: Dairy heifer morbidity, mortality and health management focusing on preweaned heifers. USDA-APHIS Veterinary Service, Ft. Collins, CO

NRC. 2001. Nutrient Requirements of Dairy Cattle. 7th rev. ed. Natl. Acad. Press, Washington, D.C

Pritchett, L. C., C. C. Gay, T. E. Besser, and D. D. Hancock. 1991 Management and production factors influencing immunoglobulin $\mathrm{G}_{1}$ concentration in colostrum from Holstein cows. J. Dairy Sci. 74:2336-2341

Quigley, J. D., III, and J. J. Drewry. 1998. Nutrient and immunity transfer from cow to calf pre- and postcalving. J. Dairy Sci. 81:2779-2790.

Rajala, P., and H. Castrén. 1995. Serum immunoglobulin concentrations and health of dairy calves in two management systems from birth to 12 weeks of age. J. Dairy Sci. 78:2737-2744.

Roy, J. H. B. 1980. Factors affecting susceptibility of calves to disease J. Dairy Sci. 63:650-664.

Staley, T. E., and L. J. Bush. 1985. Receptor mechanisms of the neonatal intestine and their relationship to immunoglobulin absorption and disease. J. Dairy Sci. 68:184-205.

Stott, G. H., and A. Fellah. 1983. Colostral immunoglobulin absorption linearly related to concentration for calves. J. Dairy Sci 66:1319-1328

Stott, G. H., D. B. Marix, B. E. Menefee, and G. T. Nightengale 1979a. Colostral immunoglobulin transfer in calves 2. The rate of absorption. J. Dairy Sci. 62:1766-1773.

Stott, G. H., D. B. Marix, B. E. Menefee, and G. T. Nightengale. 1979b. Colostral immunoglobulin transfer in calves 3. Amount of absorption. J. Dairy Sci. 62:1902-1907.

Todd, A. G., and P. B. D. Whyte. 1995. The effect of delays in feeding colostrums and the relationship between immunoglobulin concentration in the serum of neonatal calves and their rates of growth Aust. Vet. J. 72:415-417.

Weaver, D. M., J. W. Tyler, and D. C. VanMetre. 2000. Passive transfer of colostral immunoglobulins in calves. J. Vet. Intern. Med. 14:569-577.

Wells, S. J., D. A. Dargatz, and S. L. Ott. 1996. Factors associated with mortality to 22 days of life in dairy herds in the United States. Prev. Vet. Med. 29:9-19. 